\title{
Hydropower Nepal
}

\author{
By Khadga Bahadur Bista, Author \\ Kathmandu, Nepal: Independent Power Producers' Association Nepal (IPPAN) \\ 293pp., NRs.5,000 (US\$150)
}

$\mathbf{H}$ ydropower Nepal is a reference book on hydropower sector related information in Nepal. It is not limited to hydropower only, however, as the author presents other general information of Nepal including an introduction to Nepal, the Himalayas, the rivers, the history of power development, and a timeline of modern Nepal. It is a detailed book on the subject with several stunning large size photographs. For foreigners coming to Nepal in power sector it is a 'must read' book for background information.

In addition to ten sections, there are four Annexes:

- Articles from the pages of Gorkhapatra (national daily newspaper of Nepal)

- River Inventory

- Hydropower Development Policy, 2001

- Timeline Nepal.

The following is a section-wise review:

1. Nepal, an Introduction deals with ancient Nepal, unification by King Prithvi Narayan Shah, role of the Ranas, armed insurgency, dawn of a Republic, geography and economy.

2. Power Sector of Nepal addresses energy consumption and presents a brief introduction to many hydropower related institutions. The author mentions that $64 \%$ of the total amount earmarked for the energy sector is spent on petroleum, which only provides $8 \%$ of the total energy. He also notes that the $27 \%$ spent on the hydropower sector provides only $1.7 \%$ of the total energy of the country.

3. Hydropower Basics describes different types of schemes, such as Run-of-River and storage systems. It has benchmarked Nepal with six other countries for hydro development. Attractive photos are presented of various types of dams, turbines, etc.

4. Hydropower Development begins with Dr. Hariman Shrestha's famous thesis on 83,000 MW Nepal's theoretical potential, then goes on to reveal that Nepal is not the second richest nation in hydropower potential, as is often said. The author also presents a step-by-step framework for hydropower development in Nepal. And he describes some of the existing barriers to hydropower development in Nepal.
Further, the author shed lights on load shedding and the reasons why. He also discusses the Maoist political party's agenda of 10,000 MW target in ten years time.

The author focus on the general arguments in hydropower sector, namely small verses big projects and domestic verses export projects.

He suggests fuel mix and energy security, and hopes that thermal generation either in Nepal or across border will be positive for Clean Development Mechanism.

5. Great Himalayas and Water deals with the geology of the Himalayan region and the fact that the Himalayas is the largest fresh water source after the Arctic, Antarctica, Greenland, and Alaska. The author feels that due global warming there will be reduced water flow in the rivers, which may have serious negative impacts on hydropower development.

6. Rivers of Nepal contains river basin sketch, enlarged plans, longitudinal section (profile) of the important rivers including a month-wise averaged flow in selected rivers. This section will be very useful for those interested in Nepal's river system.

7. Power Plants of Nepal contains all the hydropower projects of Nepal from Pharping (500 kW) to Upper Tamakoshi HEP (456 MW) with photographs, salient features and important parameters of the projects. The author does not mention, however, that the Phewa and Tinau hydro plants (1 MW each) are running at only a fraction of their installed capacity; hence, this reviewer feels that they need to be leased out to the private sector.

8. Power Transmission and Distribution includes a Power Development Map, a Power Map of Nepal, and tables of the transmission/distribution lines (constructed, under construction and proposed). Currently, there are numerous problems (such as permission for tree felling) in transmission line construction/rehabilitation, factors that are not sufficiently highlighted in the book.

9. Corporate Social Responsibility in Hydropower describes the theory of CSR in Hydropower. Since the enactment of Environment Protection Act of 2054 (EPA 1997), CSR activity has been mandatory and several projects have taken it as their responsibility. The works of the Butwal Power Company (BPC) and 
US\$ 10 million for CSR in the Khimti (6o MW) area by Himal Power Limited (HPL) are described. The author cautions that there are more demands, threats and pressure from far fletched areas to be included that are not possible to bear by a single hydropower project.

10. Towards a New Hydropower Century presents tables of the under construction and proposed projects for next five, ten, 15 and 20 years, and the author looks forward for 25,000 MW in the coming 20 years. The author seems to be confident of this vision; whereas the reality is that there are 101 various barriers hampering the hydropower sector. Therefore, enhanced hydro project implementation will be a Herculean task. In short, the book does not sufficiently address the various barriers in the way of efficient hydro development.

\section{Conclusions}

This is a good reference book on Hydropower in Nepal. It provides additional useful information about Nepal such as brief timeline, geography, the great Himalayas, river system, etc., which will be useful to the new comer to Nepal. The salient features of the hydro projects are detailed. There are plans, large size river profiles with monthly average river flow data, and brief discussion of barriers in hydro development. The book is well illustrated with many large size photographs and other graphics.

This book gives the impression that the author is confident about large hydropower development in coming years. But the reality on the ground is different. Unless some strong measures are taken there will be no substantial development in hydropower due to various impediments. This aspect is not sufficiently mentioned in the book.

It took the Nepalese bureaucracy 20 years to understand that the private sector is not capable of fulfilling the needs of the country and that the public sector must step in for large size projects. Furthermore, politicians and bureaucrats will also learn with experience that India's power market is not open for Nepal (unless developed by Indian companies). The failure of 15 years of efforts for the implementation of West Seti HEP (750 MW for export) is a stunning example. Unless and until the leadership of the nation and a political consensus demonstrate sincere commitment and some drastic measures are taken, the end of load shedding in Nepal will remain a distance dream.

Finally, the price of the book is astoundingly high at NRs. 5,000.00 per copy (US\$ 150), which limits access and usefulness to a certain class of readership. Nonetheless, this reviewer acknowledges the author's hard and dedicated job of producing the book.

\section{ICIMOD is pleased to announce the release of a new publication, 'Flash Flood Risk Management - A Training of Trainers Manual'}

$\mathbf{U}^{2}$ Tnstable geological conditions and steep topography, combined with frequent extreme weather conditions, make the Hindu KushHimalayan (HKH) region prone to many natural hazards. Among these, flash floods - severe flood events that occur with little warning - are particularly challenging for communities, threatening lives, livelihoods, and infrastructure. Vulnerable groups such as the poor, women, children, the elderly, and people with disabilities are often the hardest hit. This Training of Trainers Manual is designed to help build the capacity of trainers in flash flood risk management, who can then disseminate the knowledge to a larger number of practitioners. The manual presents an eight-day course including a threeday field trip. Detailed lesson plans for 21 sessions are followed by resource materials that will enable the trainers to replicate the course in their own work areas. Designed for participants with a basic knowledge of flash flood risk assessment and management, the manual focuses on

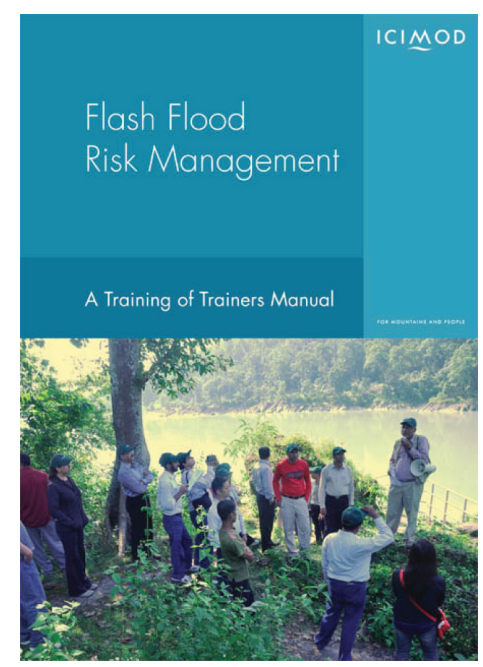

developing understanding of the types, causes, and impacts of flash floods; flash flood hazards, vulnerability, risk assessment, and management methods; the role of local knowledge and gender perspectives in flash flood risk management; participatory social hazard mapping techniques; concepts and methods for an integrated approach to flash flood risk management; the full range of risk management measures for specific types of flash floods; legal and institutional aspects; and modelling tools. It is hoped that the publication will contribute meaningfully towards reducing disaster risk and providing greater physical security for the people of this vulnerable region.

Printed copies are available from the Distribution Unit.

The full publication can also be downloaded from ICIMOD Books Online at

http://www.icimod.org/publications/index.php/ search/publication/783. 